form of calcium phosphate, the plant is able to obtain enough phosphorus for its use, since calcium phosphate is soluble enough to supply the needs of a growing crop.

UNIVERSTTY OF WISCONSIN,

Department of Soils.

[CONTribution From The BUREAU OF CheMistry, DFPartMent OF AGriculTURE. Sent by H. W. WILEY.]

\title{
THE PREPARATION OF VINEGAR FROM KIEFFER PEARS
}

By H. C. Gore.

The Kieffer pear is a large, coarse fleshed variety of pear extensively grown in various parts of the United States, largely on account of the productiveness of the trees and their resistance to blight. In seasons when large crops of the choicer varieties of pears are produced, or when the apple crop is large, the prices obtainable for Kieffer pears are often too low to pay for marketing. It is desirable, therefore, to find some use for surplus Kieffer pears. At the suggestion of Mr. Wm. A. Taylor, Pomologist in charge of Field Investigations, of the Department of Agriculture, experiments were undertaken to determine if good vinegar could be made from the juice of Kieffer pears.

\section{Experimental Work.}

(a) Preparation of the Juice. - This portion of the work was carried on under the supervision of Mr. W. F. Fletcher, of the office of Field Investigations in Pomology. The pears were grown near Washington, $D$. C. The fruits were very ripe, many of them being quite soft. Six barrels of fruit were employed. These were ground at the mill of $\mathrm{Mr}$. T. M. Whitney, at Washington, D. C., on October I6, I905, at about 5 p. m. The juice and pomace were allowed to macerate over night in a wooden vat and were pressed on the following morning. The juice ran from the cheeses readily, a high yield being readily obtained from the large handpower press which was used. From data secured by Mr. Fletcher at the time of pressing, the yield of juice was found to be $4 \frac{1}{2} / 2$ gallons per bushel of fruit.

(b) Preparation of Perry from the Juice by Alcoholic Fermentation. - The juice was poured at once into two clean, 50-gallon whiskey barrels and stored in an unheated shed. As soon as received at the shed, a few gallons were removed from each barrel, in order to leave space for the formation of a head; no such formation, however, was observed.

One barrel of juice was allowed to ferment spontaneously by action of the wild yeasts present. To the other barrel, dominant fermentation by a special yeast was secured by adding a small quantity of a pure culture of a cider yeast supplied by Mr. W. B. Alwood. Throughout the fermentation the barrels were kept closed with cotton plugs. Samples of 
juice were taken for analysis at once, and at intervals throughout the fermentation. Fermentation set in rapidly in both barrels of juice. The analytical results are given graphically in Chart $\mathrm{I}$.

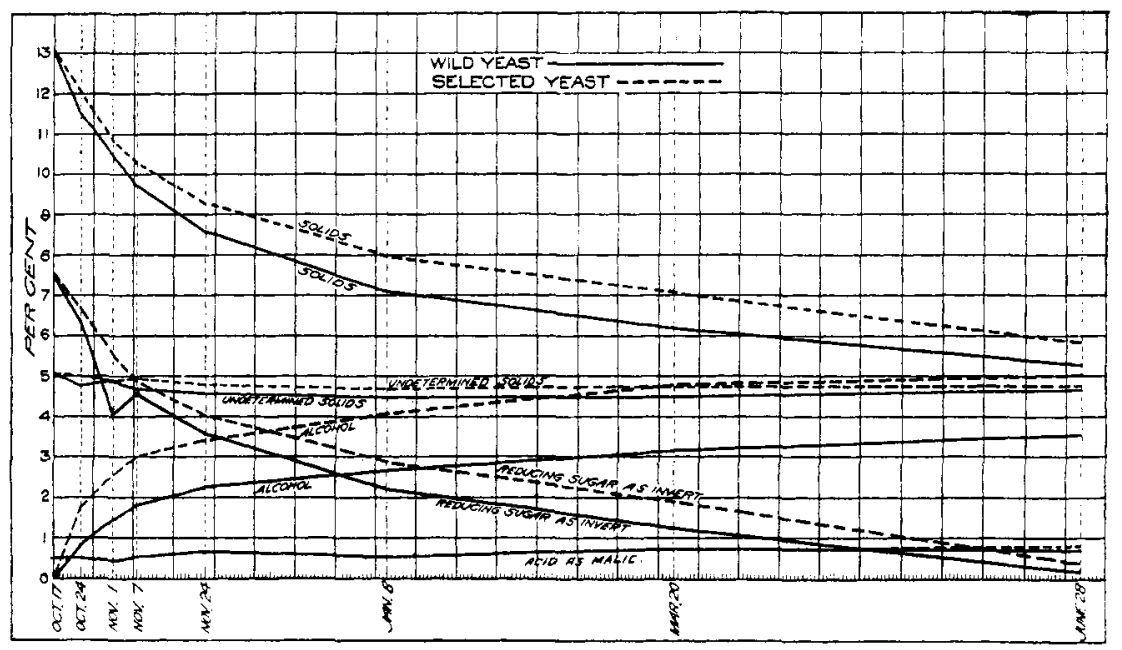

The solids were determined in each case by heating samples of te ${ }^{11}$ grams in flat aluminum dishes to nearly constant weight in a partial vacuum at a pressure of a few inches of mercury at $70^{\circ} \mathrm{C}$.

The value called undetermined solids is the difference between the total solids and the sum of the reducing sugar and the original quantity of acid expressed as malic. During fermentation there was undoubtedly some decrease in non-volatile acid, which was masked by the formation of volatile acid. No determination can be made of this loss, however, since the volatile acid was not determined. The undetermined solids consist of unknown carbohydates together with small amounts of ash and protein, and also, in case of the fermented juices, of small quantities of the by-products of the fermentation, glycerol, etc.

The analyses made on October 24, just after fermentation had started, show at once that more alcohol is formed than theoretically is possible from the sugar consumed. The only explanation is that alcohol was present in the original must. As noted on page 759, the fruit was very ripe, and probably a good many fruits were partly softened by decay. Alcohol is known to occur in decaying fruits, and thus its presence in the fresh juice may be accounted for. Unfortunately, alcohol was not determined in the fresh juices.

A striking fact brought out by these analyses is the large amount of solids which remain unchanged in quantity during the fermentation of the cider. This large amount of solids persists throughout the acetic 
acid fermentation, a vinegar very high in solids being produced. See below.

The influence of dominant fermentation by a single variety of yeast is clearly shown. A higher yield of alcohol was produced by the dominant fermentation, amounting to I.2I per cent., increase of alcohol calculated on the juice, or to 33 per cent., increase of the alcohol. The controlled fermentation started more rapidly than fermentation by wild yeast. In addition, the undetermined solids are slightly, but distinctly, higher where dominant fermentation was secured, owing, probably, to the fact that the rapid multiplication of the yeast holds in check the organisms which attack these solids.

(c) Preparation of Vinegar from the Perry by Acetic Fermentation.For this work, the perry secured by the dominant fermentation by cider yeasts was employed. A sample of about seven gallons was vinegarized in a small, rapid-process vinegar generator. At the end of eleven days the maximum of acid was attained. The vinegar thus made was high in acid, and of pleasant odor and taste.

The notable features of this vinegar are its high content of solids and the considerable quantity of pentosans present. The solids consist mainly of the undetermined solids of the perry. The per cent. of solids increased on acetification owing to concentration of the perry in the generator. In order to study the solids more closely, about a liter of vinegar was evaporated in flat platinum dishes in vacuo at $70^{\circ}$ to thin sticky films, and this residue dissolved in a little water. Special determinations were then made and are given in Table $I$.

\section{TABLE I}

Showing Resuits of the Examination of Pear Vinegar Solids.

\begin{tabular}{|c|c|c|c|c|c|c|c|}
\hline Ash & Nitrogen & Pentosans & Galactans & $\begin{array}{c}\text { Reducing } \\
\text { Before } \\
\text { hydrolysis2 }\end{array}$ & $\begin{array}{l}\text { Power } 1 \\
\text { After } \\
\text { hydrolysis2 }\end{array}$ & $\begin{array}{c}\text { Before } \\
\text { hydrolysis? }\end{array}$ & $\begin{array}{l}\text { After } \\
\text { hydrolysis? }\end{array}$ \\
\hline $\begin{array}{l}\text { per cent. } \\
6.00\end{array}$ & $\begin{array}{c}\text { per cent. } \\
0.06\end{array}$ & $\begin{array}{c}\text { per cent. } \\
4.25\end{array}$ & $\begin{array}{l}\text { per cent. } \\
\text { none }\end{array}$ & $\begin{array}{c}\text { per cent } \\
8 \cdot 77\end{array}$ & $\begin{array}{c}\text { per cent. } \\
\text { II } 45\end{array}$ & $\begin{array}{c}\text { degrees } \\
-2 \cdot 3\end{array}$ & $\begin{array}{c}\text { degrees } \\
+3.2\end{array}$ \\
\hline
\end{tabular}

From these analyses it appears that the solids consist mainly of carbohydrates of unknown composition. The carbohydrates are more difficult to hydrolyze than starch, and are of low rotatory and reducing power. They are similar in these respects to the "amylans" of barley and malt recently studied by the Guiness Research Laboratory ${ }^{3}$.

Table II gives the analysis of the sample of pear vinegar in comparison with analyses of other vinegars. ${ }^{*}$ It is very similar in composition to

${ }^{\mathrm{I}}$ Reducing power means per cent. of reducing bodies present expressed in terms of dextrose.

${ }^{2} \mathrm{Hydrolysis}$ by heating with dilute $\mathrm{HCl}$ for $3 \mathrm{hrs}$, as in the method for starch.

${ }^{3}$ Trans. Guin. Research Lab. Vol. 1 Pt. 2, p. 3 I 2.

"Other vinegar analyses taken from Leach "Food Inspection and Analysis" I904. 
apple vinegar, save for the high content of solids and of pentosans. Normal apple vinegar contains practically no pentosans.'

\section{TABLE II}

SHOWING THE COMPOSITION OI KIEIFFR PHAR VINEGAR N COMPARISON WITH OTHER VINEGARS. ${ }^{1}$

Find of vinegat

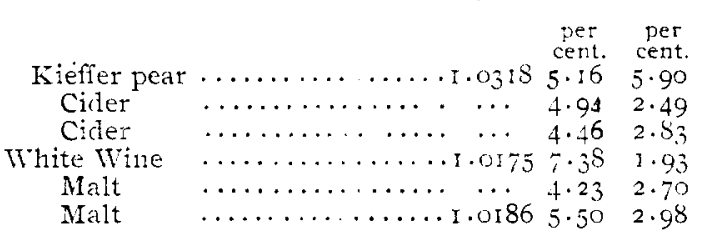

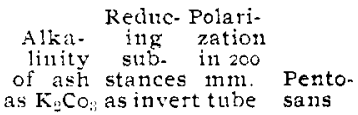

Ash as $\mathrm{K}_{2} \mathrm{CO}_{\text {; }}$ as invert tube sans

per per sugar per degs, $v$

$\begin{array}{llllll} & \text { cent, cent, cent. } & & \\ 0.32 & 0.18 & 0.45 & \cdots .1 .6 & 0.26\end{array}$

$0.34 \quad 0.20 \quad 0.25-[.3 \quad \ldots$

$0.39 \quad 0.27 \quad \ldots \quad \ldots$.

$0.32 \quad \ldots \quad 0.22 \quad \ldots \quad \ldots$

$0.34 \quad 0.04$

$0.40 \quad 0.15$

\section{The Composition of Juice of Kieffer Pears.}

Analyses were now made to determine the usual sugar content and undetermined solid content of Kieffer pears. For this work representative samples of pears were secured by Mr. Taylor from three localities where the fruit is extensively grown. The results of the analyses are given in Table III.

These results show that the juices of market-ripe Kieffer pears are too poor in sugar to produce a vinegar containing 4 per cent. of acetic acid.

A portion of the sample of pears from which juice No. 17577 was expressed, was allowed to become very ripe and the juice then analyzed. An increase of more than $2 \%$ of sugar was found. This experiment was repeated on another sample of pears with similar results, an increase of more than $1 / 2$ per cent. being noted. In this case, the sample at the time of storage was considerably riper than sample No. 17577 . Kieffer pears contain little or no starch, and it would appear that the undetermined solids become partly changed to reducing sugars during the ripening of the fruit. This point requires further experimental support, however, before it can be considered as established. It is quite clearly indicated, however, that Kieffer pears contain their maximum of sugar when very ripe, and should be ground at this time for vinegar making.

From the experimental work given above, the following conclusions are drawn:

(I) The juices of Kieffer pears at market ripeness are so low in sugar that it is impossible to produce from them a vinegar of standard strength (4 per cent. acetic acid). 'The juices of very ripe Kieffer pears probably do contain sufficient sugar to produce a standard vinegar, providing methods of fermentation are employed which will give the maximum yield of acetic acid from the sugar present.

(2) The method of fermentation of the juice into vinegar which will ${ }^{1}$ Communicated by Messrs. Tolman and LeClerc. 


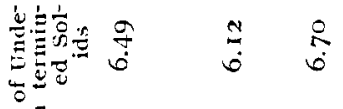

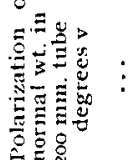

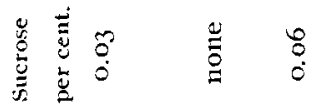

$=\stackrel{n}{*}=$

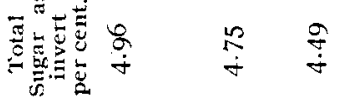

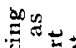

تصنّ

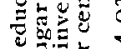

$\approx \cdot \sqrt{5}$

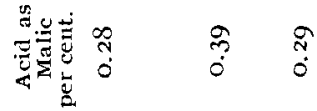

$\stackrel{0}{\circ} \stackrel{0}{0}$

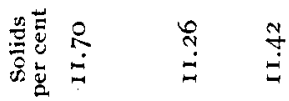

\& $n$

学

政

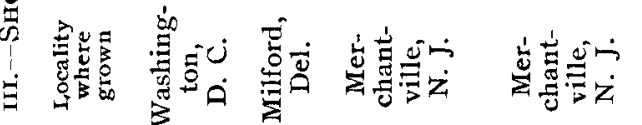

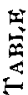

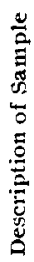

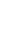

京

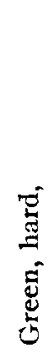

点:

io:

$\sum_{\substack{\infty \\ \hdashline}}^{\infty}$

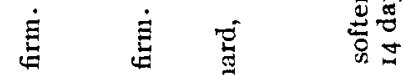

$\stackrel{2}{\varrho}$

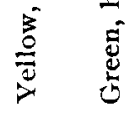

总

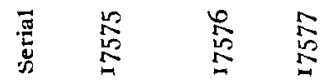

$\mathbb{D}^{\frac{1}{2}}$
营

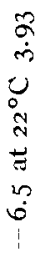

5

in

$\frac{12}{3}$

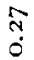

$\stackrel{2}{2}$

N

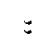

of to

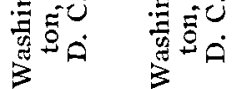

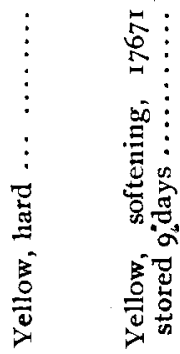


give the maximum of acetic acid, consists in the production of the maximum of alcohol from the sugar by dominant fermentation with selected yeasts, followed by the conversion of the alcoholic liquor into vinegar by the quick process of vinegar making.

(3) The vinegar obtained is of excellent quality. Its composition is similar to that of cider vinegar, save for its high content of solids, and content of pentosans.

\title{
THE EFFECT OF SHADE DURING RIPENING ON THE PROXIMATE CONSTITUENTS OF THE WHEAT KERNEL.
}

\author{
BY R. W. Thatcier aND H. R. WATKINS. \\ Received March 5, 1907.
}

Within the past few years extensive experiments in growing crops under shade have been carried out. The purpose of these investigations has been, for the most part, to influence the development of the plant in such a way as to adapt it to some market requirement. So far as we can discover, however, very little concerning the effect of the shade upon the chemical composition of the plants has been published. Berthelot ${ }^{1}$ reports analyses to show the effect of the shade of an elm tree upon the percentage content of carbou, phosphorus, sulphur, and nitrogen of crested dogtail grass cut at intervals during the growing season. Strakosch ${ }^{2}$ investigated the effect of very diffused light upon the formation of carbohydrates in the leaves of the sugar beet. Aside from these, the literature which is available to us contains no reference to the effect of shade during growth upon the nature and the percentage of the compounds which are built up in the plant.

The chemical department of the Washington State Experiment Station is making a thorough study of the conditions which affect the chemical composition and milling qualities of wheat. During the summer of 1906 , in connection with these studies, we made some preliminary investigations of the influence of direct sunlight as compared with diffused light upon these properties of the wheat kernel. The results of these experiments are so striking and so suggestive that their publication at this time seems to be warranted.

\section{DETAILS OF THE EXPERIMENT.}

The wheat was all of the Bluestem variety, a white spring wheat. Six rows of grain grown from seed coming from several different wheatproducing districts of the State were used. Just at the time when the plants began to flower, on July 12 th, a portion of the plants of each row were shaded by stretching over one end of the plot a cover. This cover was made of heavy, 16-ounce duck canvas, and was stretched just above

${ }^{1}$ Compt. Rend. 128, I39-I40, (1899).

'Separate from Öest. Ungar. Z. Zuckerind. und Landw. 1906, No. I. 